\title{
Türkiye'de Hükümetlerin Orman Kaynakları Yönetimi ve İşletmeciliğine Yönelik Bazı Uygulamalarının İrdelenmesi (1961-2012 Dönemi)
}

\author{
Ahmet Köksal COŞKUN ${ }^{1},{ }^{* *}$ Atakan ÖZTÜRK ${ }^{2}$, Mustafa Fehmi TÜRKER ${ }^{3}$ \\ ${ }^{1}$ Bursa Orman Bölge Müdürlüğü - Bursa \\ ${ }^{2}$ Artvin Çoruh Üniversitesi Orman Fakültesi Orman Mühendisliği Bölümü - Artvin \\ ${ }^{3}$ Karadeniz Teknik Üniversitesi Orman Fakültesi Orman Mühendisliği Bölümü - Trabzon \\ **Sorumlu yazar: e-posta: atakanozturk@ artvin.edu.tr
}

Geliş Tarihi:20.10.2015

\begin{abstract}
Özet
Bu araştırma ile ülkemizde 1961-2012 döneminde görev yapan hükümetlerin ormancılıkla ilgili bazı uygulamaların orman kaynakları yönetimi ve işletmeciliğine yansımaları irdelenmiştir. Araştırma kapsamında ormancılık yönetimi, odun üretimi, ağaçlandırma ve orman tesisi ile orman kadastrosu faaliyetlerine ilişkin gelişmeler ele alınmış ve Orman Genel Müdürlüğü başta olmak üzere çeşitli kurumlara ait veri ve belgeler ile ağ sayfalarından istifade edilmiştir. Hükümet dönemleri itibariyle bazı faaliyet gerçekleşmeleri arasında anlamlı fark olup olmadığının belirlenmesinde Mann Whitney U testi kullanılmıştır. Araştırmada öne çıkan sonuçlardan bazıları şunlardır: İlk defa 1969 yılında Adalet Partisi döneminde müstakil şekilde kurulan ve 1980 yılında ihtilal hükümeti tarafindan kapatılan Orman Bakanlığı, 1991 yılında Anavatan Partisi döneminde müstakilen ikinci defa kurulmuştur. Tek parti ve diğer hükümet dönemleri karşılaştırıldığında ağaçlandırmayı da içine alan orman tesisi çalışmaları açısından tek parti hükümet dönemleri lehine anlamlı bir fark söz konusu iken, endüstriyel odun üretimi açısından bir fark bulunamamıştır. Kadastro çalışmaları açısından bakıldığında, AK Parti döneminde yapılan yıllık ortalama orman kadastrosu, diğer hükümet dönemlerinde yapılanın yaklaşık altı katına karşılık gelmektedir.

Anahtar Kelimeler: Hükümet icraatları, Adalet Partisi, Anavatan Partisi, Adalet ve Kalkınma Partisi, orman kaynaklar1.

\section{Examination of Some Forest Resources Management and Administration Practices of Governments in Turkey (1961-2012 Period)}

\section{Abstract}

In this study, some forestry related practices of governments in 1961-2012 period were investigated in the context of forest resources management and administration. Within the scope of the study, developments related to forestry management, timber harvesting, afforestation, forest establishment and forest cadastre were discussed and data, documents and web pages of General Directorate of Forestry and various organizations were used in the study. Mann Whitney $U$ test was used to determine whether there is a significant difference or not between the amount of realization of certain activities by government eras. Some outstanding results of the study are such these: The Ministry of Forestry was established for the first time in 1969 by Justice Party and revoked in 1980 by the Military Government. In 1991, it was reestablished by the Motherland Party. When single-party governments and the other governments are compared, it is found that while there is a significant difference in favor of single-party governments with regard to forest establishment practices including afforestation, there is no difference in industrial wood production. Annual average forest cadastral works during the Justice and Development Party era was approximately six times more than other governments.
\end{abstract}

Key words: Actions of government, Justice Party, Motherland Party, Justice and Development Party, forest resources.

\footnotetext{
* Bu makale, Ahmet Köksal COŞKUN tarafindan Doç. Dr. Atakan ÖZTÜRK ve Prof. Dr. Mustafa Fehmi TÜRKER danışmanlığında hazırlanan "Ülkemiz Tek Parti İktidarlarında Ormancılıkla İlgili Hükümet Vaat ve İcraatlarının Orman Kaynakları Yönetimi ve İşletmeciliği Açısından Değerlendirilmesi” adlı yüksek lisans tezinin bir bölümünden istifade edilerek hazırlanmıştır.
} 


\section{Giriş}

İktidar ya da iktidar ortağı olmak amac1 ile halkın oyunu talep eden ve böylece kendi programlarını ülke yönetiminde hâkim kılmaya çalışan siyasi topluluklar (Erdoğan, 2013) olarak tanımlanan siyasi partilerin en önemli işlevi, ülkede yaşanan sorunların tespiti ve bu sorunların çözümüne dönük politika ve programların geliştirilmesidir. Halkın iktidar olan partilerden beklentisi, sorunlarının çözümüne dönük politikaların hükümet programlarına yansitılması ve akabinde icraata dönüştürülmesidir.

Ülkemiz siyasi tarihinde 1961 Anayasas1, ormancılıkta devletçilik anlayışını egemen kılmak üzere ormancılı̆̆ın özüne ilişkin hükümlerin yer aldığı ilk anayasadır (Erdönmez ve ark., 2010). Orman sayılan yerlerin ve devlet ormancilığı düzeninin korunmasının amaçlandığı (Çağlar, 2012) ve ormancılı̆̆ımız için yeni bir çığır açan (Özdönmez ve ark., 1998 ) bu düzenleme, siyasi partilerin ormanlara yönelik ilgisinde yeni bir dönemin başlamasına neden olmuştur.

$\mathrm{Bu}$ dönemde, kırsal halkın en düşük gelir seviyesine sahip kesimini oluşturan orman köylüleri ile ormanla ilişkili ilgi ve çıkar gruplarının (öbeklerinin) talep ve beklentilerinin çeşit ve sayı olarak giderek artması, partilerin seçim beyannamelerinde ve hükümet programlarında ormanlara ve ormancılık sektörüne ilişkin politikalara yer vermelerini adeta zorunlu kılmıştır (Coşkun ve ark., 2015). Bu süreci, iktidar şansını yakalayan siyasi partiler için politikaların/vaatlerin uygulamaya aktarılması yani icraata dönüştürülmesi izlemiştir. Sonuçta bu icraatların, ülkemiz orman kaynakları yönetimi ve ișletmeciliği üzerinde olumlu/olumsuz etkileri kaçınılmaz olmuştur. $\mathrm{Bu}$ dönemlerde tek başına iktidar olamayan hükümetlere nazaran tek parti hükümetlerinin daha rahat karar alma ve uygulama imkânı olduğundan, tek parti hükümetlerinin politikalarını icraata dönüştürebilmesi ve vaatleri ile icraatları arasındaki tutarlılığın da nispeten fazla olması beklenen bir durumdur.

Ülkemizde ormancılık politikaları ve mevzuatındaki değişimlerin siyasi ve toplumsal boyutlarını konu edinen (Çağlar, 2012; Benli 2014; Birben 2008; Atmiş ve
Gençay 2014), bazı siyasi partilerin seçim bildirgeleri (Atmiş 2008; Atmiş ve Günşen 2011) ile tek bir partinin hükümet programını (Atmiş ve Günşen 2009) ormancilik politikası ve uygulamaları açısından eleştirel bir bakış açısıyla irdeleyen çeşitli çalışmalara rastlanmıştır. Coşkun ve ark. (2015)'nın çalışmasında ise 1961 sonrası dönemde tek başına hükümet olmuş partilerin seçim beyannameleri ve hükümet programları karşılaştırmalı şekilde irdelenmiştir. Dolayısıyla yazın taraması sonucunda, Ülkemizde hükümetlerin kurulma şekilleri (seçimle tek başına ya da koalisyon, azınlık vb.) de dikkate alınarak ilgili dönemlerde ormancılıkla ilgili icraatlarının karşılaştırmalı olarak irdelendiği bir çalışmaya rastlanmamıştır.

$\mathrm{Bu}$ araştırma ile ülkemizde 1961-2012 döneminde seçimle tek başına iktidar olmuş parti hükümetleri (tek parti hükümetleri) ve diğer hükümet dönemlerinde ormancilıkla ilgili bazı uygulamaların orman kaynakları yönetimi ve işletmeciliğine yansımalarının irdelenmesi amaçlanmaktadır.

\section{Gereç ve Yöntem}

Ülkemizde 1961-2012 döneminde hükümetlerin ormancılıkla ilgili bazı icraatlarının irdelenmesi amaciyla ele alınan araştırmanın temel malzemesini, Türkiye Büyük Millet Meclisi (TBMM), Başbakanlık, Orman ve $\mathrm{Su}$ İşleri Bakanlığı, Türkiye İstatistik Kurumu (TÜİK) ve Orman Genel Müdürlüğ̈̈ (OGM)'nden alınan veri ve belgeler ile konu ile ilgili diğer bilimsel çalışmalar ve ağ sayfaları oluşturmuştur (Coşkun, 2013).

Araştırma döneminde Ülkemizde 38 farklı hükümet kurulmuștur (Coşkun, 2013). Bunlardan 11 adedi seçimle gelip tek başına iktidar olabilen üç farklı parti (Adalet Partisi (AP), Anavatan Partisi (ANAP) ve Adalet ve Kalkınma Partisi (AK Parti)) tarafindan kurulan tek parti hükümetleridir. Söz konusu tek parti hükümetlerinin ortalama hükümet süresi 2,5 y1l olarak gerçeklemiştir. Kalan 27 hükümet ise azınlık, partiler üstü, ihtilal ve koalisyon olarak adlandırılan hükümetler olup, bunların da ortalama süresi 1,5 y1l olarak gerçekleşmiştir (Tablo 1). Bunlardan mecliste yeterli çoğunluğa sahip olamayan azınlık hükümetleri (6 adet) ile seçimlerle 
işbaşına gelmemiş olan partiler üstü (2 adet) ve ihtilal ( 3 adet) hükümetleri olağan üstü durumlarda kurulmuş olan hükümetlerdir. Öte yandan, aynı dönemde Ülkemizde en yaygın görülen (16 adet) hükümet şekli koalisyon (ortaklık) hükümetleridir. Seçimler sonucunda tek başına iktidar olamayan birden fazla partinin bir araya gelmesiyle kurulan koalisyon hükümetleri genellikle güçsüz, hızlı karar alma ve uygulama yeteneği nispeten düşük hükümetler olarak nitelendirilmektedir (Gözler, 2000).

Tablo 1. Ülkemizde 1961 y1lından sonra kurulan hükümetler

\begin{tabular}{|c|c|c|c|c|}
\hline No & Adı & Görev Süresi & Başbakanı & Hükümet Şekli \\
\hline 24 & I. Gürsel Hükümeti & $30.05 .1960-05.01 .1961$ & Cemal Gürsel & İhtilal \\
\hline 25 & II. Gürsel Hükümeti & 05.01.1961-20.11.1961 & Cemal Gürsel & İhtilal \\
\hline 26 & VIII. İnönü Hükümeti & 20.11.1961-25.06.1962 & İsmet İnönü & Koalisyon \\
\hline 27 & IX. İnönü Hükümeti & $25.06 .1962-25.12 .1963$ & İsmet İnönü & Koalisyon \\
\hline 28 & X. İnönü Hükümeti & $25.12 .1963-20.02 .1965$ & İsmet İnönü & Koalisyon \\
\hline 29 & Ürgüplü Hükümeti & $20.02 .1965-27.10 .1965$ & Suat Hayri Ürgüplü & Koalisyon \\
\hline 30 & I. Demirel Hükümeti & $27.10 .1965-03.11 .1969$ & Süleyman Demirel & Tek Parti (AP) \\
\hline 31 & II. Demirel Hükümeti & $03.11 .1969-06.03 .1970$ & Süleyman Demirel & Tek Parti (AP) \\
\hline 32 & III. Demirel Hükümeti & $06.03 .1970-26.03 .1971$ & Süleyman Demirel & Tek Parti (AP) \\
\hline 33 & I. Erim Hükümeti & 26.03.1971-11.12.1971 & Nihat Erim & Partiler üstü \\
\hline 34 & II. Erim Hükümeti & $11.12 .1971-22.05 .1972$ & Nihat Erim & Partiler üstü \\
\hline 35 & Melen Hükümeti & $22.05 .1972-15.04 .1973$ & Ferit Melen & Koalisyon \\
\hline 36 & Talu Hükümeti & $15.04 .1973-26.01 .1974$ & Naim Talu & Koalisyon \\
\hline 37 & I. Ecevit Hükümeti & 26.01.1974-17.11.1974 & Bülent Ecevit & Koalisyon \\
\hline 38 & Irmak Hükümeti & 17.11.1974-31.03.1975 & Sadi Irmak & Azınlık \\
\hline 39 & IV. Demirel Hükümeti & $31.03 .1975-21.06 .1977$ & Süleyman Demirel & Koalisyon \\
\hline 40 & II. Ecevit Hükümeti & $21.06 .1977-21.07 .1977$ & Bülent Ecevit & Azınlık \\
\hline 41 & V. Demirel Hükümeti & 21.07.1977-05.01.1978 & Süleyman Demirel & Koalisyon \\
\hline 42 & III. Ecevit Hükümeti & $05.01 .1978-12.11 .1979$ & Bülent Ecevit & Azınlık \\
\hline 43 & VI. Demirel Hükümeti & $12.11 .1979-12.09 .1980$ & Süleyman Demirel & Azınlık \\
\hline 44 & Ulusu Hükümeti & $20.09 .1980-13.12 .1983$ & Bülent Ulusu & İhtilal \\
\hline 45 & I. Özal Hükümeti & 13.12.1983-21.12.1987 & Turgut Özal & Tek Parti (ANAP) \\
\hline 46 & II. Özal Hükümeti & 21.12.1987-09.11.1989 & Turgut Özal & Tek Parti (ANAP) \\
\hline 47 & Akbulut Hükümeti & 09.11.1989-23.06.1991 & Ylldırım Akbulut & Tek Parti (ANAP) \\
\hline 48 & I. Yılmaz Hükümeti & $23.06 .1991-20.11 .1991$ & Mesut Yllmaz & Tek Parti (ANAP) \\
\hline 49 & VII. Demirel Hükümeti & $21.11 .1991-25.06 .1993$ & Süleyman Demirel & Koalisyon \\
\hline 50 & I. Çiller Hükümeti & 25.06.1993-05.10.1995 & Tansu Çiller & Koalisyon \\
\hline 51 & II. Çiller Hükümeti & 05.10.1995-30.10.1995 & Tansu Çiller & Azınlık \\
\hline 52 & III. Çiller Hükümeti & $30.10 .1995-06.03 .1996$ & Tansu Çiller & Koalisyon \\
\hline 53 & II. Yılmaz Hükümeti & $06.03 .1996-28.06 .1996$ & Mesut Yılmaz & Koalisyon \\
\hline 54 & Erbakan Hükümeti & $28.06 .1996-30.06 .1997$ & Necmettin Erbakan & Koalisyon \\
\hline 55 & III. Yılmaz Hükümeti & 30.06 .1997 - 11.01.1999 & Mesut Yılmaz & Koalisyon \\
\hline 56 & IV. Ecevit Hükümeti & $11.01 .1999-28.05 .1999$ & Bülent Ecevit & Azınlık \\
\hline 57 & V. Ecevit Hükümeti & 28.05.1999-18.11.2002 & Bülent Ecevit & Koalisyon \\
\hline 58 & Gül Hükümeti & $18.11 .2002-14.03 .2003$ & Abdullah Gül & Tek Parti (AK Parti) \\
\hline 59 & I. Erdoğan Hükümeti & $14.03 .2003-29.08 .2007$ & Recep Tayyip Erdoğan & Tek Parti (AK Parti) \\
\hline 60 & II. Erdoğan Hükümeti & 29.08.2007-06.07.2011 & Recep Tayyip Erdoğan & Tek Parti (AK Parti) \\
\hline 61 & III. Erdoğan Hükümeti & $06.07 .2011-28.08 .2014$ & Recep Tayyip Erdoğan & Tek Parti (AK Parti) \\
\hline
\end{tabular}

Gerek hükümet oluş şekilleri ve ortalama hükümet süreleri gerekse karar alma ve uygulama yetenekleri/güçleri itibariyle tek parti hükümetlerinden belirgin şekilde farklılık gösteren; azınlık, partiler üstü, ihtilal ve koalisyon hükümetlerinin tamamı araştırma kapsamında ayrı bir hükümet grubu olarak ele alınmıştır. Böylece araştırmanın kapsam1; AP, ANAP ve AK Parti tarafindan kurulan tek parti hükümetleri ile koalisyon $v^{*}$. hükümetler olarak sınırlandırılmıştır.

Ülkemizde orman kaynaklarının sürdürülebilir yönetimi ile toplum refahına

\footnotetext{
* Bu makalede; koalisyon, azınlık, partiler üstü ve ihtilal hükümetlerinin tümü için "koalisyon vd." ifadesi kullanılmıștır.
} 
ve ülkenin sürdürülebilir kalkınmasına en uygun katkıların sağlanması temel amacı doğrultusunda tanımlanan ulusal ormancılık amaçları; ormanların korunması, iyileştirilmesi ve faydalanmaya konu edilmesi şeklinde üç ana başlık altında toplanmaktadır (Anonim, 2004). Ormanların tamamına yakınının devlet mülkiyetinde olması, bu amaçlara ulaşma noktasında hükümetlerin ormancillkla ilgili uygulamalarını önemli araçlar haline getirmiştir. $\mathrm{Bu}$ nedenle ilgili dönemdeki hükümetlerin icraatlarının kapsamı; ulusal ormancılık amaçlarına hizmet eden ve aynı zamanda Ülkemiz ormancilığının uzun y1llardan beri çözülemeyen temel ya da kök sorunları arasında sayılan (Türker ve Yılmaz, 2010); ormanc1lık yönetimi (örgütü), odun üretimi, ağaçlandırma ve orman tesisi ile orman kadastrosuna ilişkin uygulamalar şeklinde sinırlandırılmıştır. Araştırmada söz konusu uygulamalar kapsamında yaşanan bazı gelişmeler tek parti hükümetlerinin birbirleriyle veya tek parti hükümetleri ile koalisyon vd. hükümet dönemleri itibariyle karşılaştırılması suretiyle incelemeye konu edilmiştir.

Çalışmada ormancılık yönetimine ilişkin gelişmeler tarihsel süreçte bakanlık düzeyinde örgütlenme şekilleri esas alınarak irdelenirken, diğer uygulamalara ilişkin gerçekleşmelerin istatistiksel analizlerinde IBM SPSS (Statistical Package for Social Sciences) 19 ve grafiklerinin çiziminde de Microsoft Excel paket programlarından istifade edilmiștir. Ağaçlandırma ve orman tesisi ile odun üretimine ilişkin y1llık gerçekleşmelerin tek parti hükümetleri (AP, ANAP ve AK Parti) ile koalisyon vd. hükümet dönemlerine göre farkl111k gösterip göstermediğinin belirlenmesinde MannWhitney $U$ Testinden istifade edilmiştir (Özdamar, 2004).

\section{Bulgular ve Tartışma \\ Ormancılık Yönetimine İlișkin Gelişmeler}

Cumhuriyetin ilk yıllarında İktisat ve Tarım Bakanlıkları bünyesinde yer alan ormancılık örgütlenmesi, 1970'li yıllarda çok boyutlu devlet ormancılığına geçişle birlikte önemli değişiklikler yaşamaya başlamıştır. $\mathrm{Bu}$ değişikliklerin önemli bir bölümü $\mathrm{AP}$,
ANAP ve AK Parti tarafindan kurulan tek parti hükümeti dönemlerinde gerçekleşmiştir. Bununla birlikte söz konusu süreçte OGM'nin tüm bakanlıklarda ormanc1lıkla ilgili başlıca birim olma özelliği ve OGM Merkez Birimleri (Daire Başkanlıkları), Orman Bölge Müdürlükleri, Orman İşletme Müdürlükleri ve Orman İşletme Şeflikleri biçimindeki geleneksel örgütlenme biçimi korunmuştur (Anonim, 1989; Anonim, 2001; Anonim, 2013a; Çağlar, 2012). 1961 sonras1 dönemde Ülkemiz ormancılığının bakanlık düzeyindeki örgütlenmesi Tablo 2'de sunulmuştur.

1961 sonrası kurulan tek parti hükümeti dönemlerinde ormancilık yönetimine ilişkin yaşanan bazı gelişmeler şu şekilde özetlenebilir (Anonim, 2001; URL, 1; Daşdemir, 2011; Çağlar, 2012):

Türkiye tarihinde ilk defa I. Demirel Hükümeti yani AP döneminde ormancılık faaliyetlerini müstakilen ve hizmet esasına göre teșkilatlanarak yürütmek üzere, 07.08.1969 tarihinde Orman Bakanlığ kurulmuştur. Ormancılığın ülke yönetiminde bakanlık düzeyinde temsil edilmesi, ormancılık teşkilatı çalışanları açısından bir güven ve isteklendirme (motivasyon) unsuru olmuştur. Ayrıca Orman Bakanlığının kurulmasıyla başlayan bu süreç, ormancılık anlayışının giderek büyük ölçüde değişmesine yol açan kurumsal düzenlemeleri de beraberinde getirmiştir. Nitekim bakanlık yapılanmasında önceden beri var olan OGM, bağlı kuruluş olarak yer alırken, 1969 yılında Ağaçlandırma ve Erozyon Kontrolü Genel Müdürlüğü (AGM), 1970 yılında Orman Ürünleri Sanayi Genel Müdürlüğü (ORÜS) ve Orman-Köy İlișkileri Genel Müdürlüğü (ORKÖY) kurulmuștur. AP'nin tek başına iktidarının sona ermesinin ardından 1976 yılında ise Milli Parklar ve Avcıllk Genel Müdürlüğü (MP) kurulmuştur. 
Tablo 2. 1961 sonrası dönemde ormanc1lık faaliyetlerinden sorumlu bakanlıklar ve birimler

\begin{tabular}{|c|c|c|c|}
\hline Bakanlık Adı & Dönem & Ormancılıkla ilgili bakanlık birimleri & Hükümet Şekli \\
\hline Tarım & $1960-1965$ & Orman Genel Müdürlüğü & Koalisyon vd. \\
\hline Tarım & 1965-1969 & Orman Genel Müdürlüğü & Tek parti $(A P)$ \\
\hline Orman & $1969-1971$ & $\begin{array}{l}\text { Orman Genel Müdürlüğ̈̈ } \\
\text { Ağaçlandırma ve Erozyon Kontrolü Genel Müdürlü̈̆̈̈ } \\
\text { Orman Urünleri Sanayi Genel Müdürlüğ̈̈ } \\
\text { Orman-Köy Ilişkileri Genel Müdürlüğü } \\
\text { Milli Parklar ve Avcllk Genel Müdürlüğ̈̈ }\end{array}$ & Tek parti $(A P)$ \\
\hline Orman & $1971-1980$ & $\begin{array}{l}\text { Orman Genel Müdürlüğü } \\
\text { Ağaçlandırma ve Erozyon Kontrolü Genel Müdürlüğg̈u } \\
\text { Orman Ürünleri Sanayi Genel Müdürlüğ̈̈ } \\
\text { Orman-Köy İlişkileri Genel Müdürlüğü } \\
\text { Milli Parklar ve Avc1lık Genel Müdürlüğü }\end{array}$ & Koalisyon vd. \\
\hline Tarım ve Orman & $1980-1983$ & $\begin{array}{l}\text { Orman Genel Müdürlüğü } \\
\text { Orman Ürünleri Sanayi Genel Müdürlüğü }\end{array}$ & Koalisyon vd. \\
\hline Tarım, Orman ve Köyişleri & 1983-1991 & $\begin{array}{l}\text { Orman Genel Müdürlüğ̈̈ } \\
\text { Orman Ürünleri Sanayi Genel Müdürlüğ̈̈ }\end{array}$ & Tek parti (ANAP) \\
\hline Orman & 1991-1991 & $\begin{array}{l}\text { Orman Genel Müdürlüğü } \\
\text { Ağaçlandırma ve Erozyon Kontrolü Genel Müdürlüğ̈̈ } \\
\text { Orman ve Köy Ilişkileri Genel Müdürlüğü } \\
\text { Milli Parklar ve Av Yaban Hayatı Genel Müdürlüğü (MPAY) }\end{array}$ & Tek parti (ANAP) \\
\hline Orman & 1991-2002 & $\begin{array}{l}\text { Orman Genel Müdürlüğü } \\
\text { Ağaçlandırma ve Erozyon Kontrolü Genel Müdürlüğü } \\
\text { Orman ve Köy İlişkileri Genel Müdürlüğü } \\
\text { Milli Parklar ve Av Yaban Hayatı Genel Müdürlüğü }\end{array}$ & Koalisyon vd. \\
\hline Orman & $2002-2003$ & $\begin{array}{l}\text { Orman Genel Müdürlüğ̈̈ } \\
\text { Ağaçlandırma ve Erozyon Kontrolü Genel Müdürlüğü } \\
\text { Orman ve Köy İlişkileri Genel Müdürlüğ̈̈ } \\
\text { Milli Parklar ve Av Yaban Hayatı Genel Müdürlüğüu }\end{array}$ & $\begin{array}{l}\text { Tek parti } \\
\text { (AK Parti) }\end{array}$ \\
\hline Çevre ve Orman & $2003-2011$ & $\begin{array}{l}\text { Orman Genel Müdürlüğü } \\
\text { Ağaçlandırma ve Erozyon Kontrolü Genel Müdürlüğ̈̈ } \\
\text { Orman-Köy Illişkileri Genel Müdürlüğü } \\
\text { Doğa Koruma ve Milli Parklar Genel Müdürlüğü (DKMP) }\end{array}$ & $\begin{array}{l}\text { Tek parti } \\
\text { (AK Parti) }\end{array}$ \\
\hline Orman ve Su Issleri & $2011-2012$ & $\begin{array}{l}\text { Orman Genel Müdürlüğ̈̈ } \\
\text { Çölleşme ve Erozyonla Mücadele Genel Müdürlüğ̈̈ (ÇEM) } \\
\text { Doğa Koruma ve Milli Parklar Genel Müdürlügüü }\end{array}$ & $\begin{array}{l}\text { Tek parti } \\
\text { (AK Parti) }\end{array}$ \\
\hline
\end{tabular}

Yine AP döneminde Orman Bakanlığı'nın merkez kuruluşunda çok boyutlu devlet ormancılı̆̆ı çalışmalarının etkinliğini artırabilecek; Yüksek Fen Kurulu, Planlama ve Koordinasyon Dairesi Başkanliğ ve Teknik Araştırma Dairesi Başkanlığ vb. birimlere de yer verilmiştir. Bu kapsamda kurulan bir diğer birim olan Ormancılık Yüksek Danışma Kurulu ise, Orman Bakanlığı'nın 2000'li yıllarda çokça sözü edilen katılımcılık ilkesiyle tasarlandığının bir göstergesi olarak değerlendirilebilir.

Öte yandan, I, II ve III. Demirel Hükümetleri dönemlerinde ormancilık yönetimine ilişkin diğer bazı gelişmeler şunlardır (Çağlar, 2012; URL, 2; URL, 3):

- 1965 y1lında OGM'de bir Bilgi İşlem Merkezi kurulmuş, Ülkemizde daha sonra yapılan seçimlerin sonuçları ilk defa buradan TRT aracıllğı ile halka duyurulmuştur.

- Başmüdürlükler bünyesinde Yol Planlama Grup Müdürlükleri ve Yol Etüt
Aplikasyon Ekip Şeflikleri kurularak Orman Yolları Şebeke Planlaması çalışmalarına başlanmıştır.

- FAO destekli Ormancilık ve Orman Ürünleri Sanayi Geliştirme Projesi hazırlanmıș ve uygulamaya bașlanmıștır.

- 1962'de kurulan Kavakçı1lık Araştırma Enstitüsü'nün çalışma alanları genişletilmiş, 1968 yılında da adı, Kavak ve Hızlı Gelişen Yabanc1 Tür Orman Ağaçları Enstitüsü olarak değiştirilmiştir.

AP döneminin ardından örgütsel gelişim sürecinde, Orman Bakanlığının 1981 yılında Tarım Bakanlığına devri ile ormancılığa ait müstakil bakanlık dönemi sona ermiş ve merkez ve taşra örgütlerinde değişime gidilmiştir. Akabinde 1983 yılında da Tarım, Orman ve Köyişleri Bakanlığı kurulmuş ve ormancilık hizmetleri 1991 y1lına kadar bu bakanlığın bünyesinde yer alan OGM tarafindan yürütülmüştür. 
Ormancılığın ikinci defa müstakil bir bakanlık olması, ANAP'ın tek başına iktidarında I. Yılmaz Hükümeti döneminde gerçekleşmiştir. $\mathrm{Bu}$ dönemde 07.08.1991 tarih ve 442 sayıl1 Kanun Hükmünde Kararname ile Orman Bakanlığ yeniden kurulmuş ve ormancilık hizmetleri de yeniden merkezde bakanlığa bağlı 4 genel müdürlük (OGM, AGM, ORKÖY, MPAY) ve taşrada bu genel müdürlüklerin çok sayıda birimi vasıtasıyla yürütülmeye başlanmıștır.

Orman Bakanlığ 1991 yılındaki kuruluşunun ardından 2003 yılında bir başka tek başına iktidar olan AK Parti tarafindan 4856 say1lı kanunla Çevre ve Orman Bakanlıkları birleştirilerek, Çevre ve Orman Bakanlığ1 (ÇOB) kurulmuş ve ormancılık hizmetleri bu bakanlığa bağlı 4 genel müdürlük (OGM, AGM, ORKÖY, DKMP) tarafından yürütülmeye başlanmıştır. Son olarak yine AK Parti tek başına hükümeti döneminde 29.6.2011 tarihinde 645 sayıl1 Kanun Hükmünde Kararname ile Orman ve $\mathrm{Su}$ İşleri Bakanlığı (OSIBB) kurulmuştur. Daha önce genel müdürlük şeklinde örgütlenen AGM ve ORKÖY yeni bakanlık örgütlenmesinde OGM'ye bağlı daire başkanlıklarına dönüştürülmüştür. Ayrıca ilgili Bakanlığın yeni hizmet birimleri kapsamında ÇEM kurulmuş ve böylece ormancılık faaliyetleri üç genel müdürlüğün (OGM, ÇEM DKMP) sorumluluğuna girmiştir. Yine 29.6.2011'den önce ÇOB'a bağlı olan 11 adet Ormancılık Araştırma Müdürlüğü de OGM'ye doğrudan bağlı taşra birimleri haline getirilmiștir.

Yazıc1 (1990) AP tek parti hükümeti (I. Demirel Hükümeti) döneminde müstakil bir bakanlığın kurulmasıyla başlayan ve 1980 y1lına kadar süren dönemi, ormancılık faaliyetlerinin bağımsız bir Orman Bakanlığı ile bu bakanlığa bağlı 5 genel müdürlük tarafından yürütülmesi dolayısıyla ormancılığın örgütsel açıdan zirveye ulaştığı dönem olarak ifade edilebileceğini belirtmektedir. $\mathrm{Bu}$ açıdan bakıldığında ANAP tek parti hükümetlerinin son döneminde (I. Y1lmaz Hükümeti) kurulan ve 4 genel müdürlükten oluşan müstakil Orman Bakanlığ 1 için de benzer bir değerlendirme yap1labilir. Ancak ormanc1lıkla ilgili müstakil bir bakanlığın varlığı, söz konusu dönemlerde örgütsel açıdan hiçbir sorun yaşanmadığ anlamına da gelmemektedir. Nitekim, bahse konu dönemlerde bağl1 kuruluş olan OGM ile Bakanlığın, taşrada iki ayrı bölge müdürlügü şeklinde örgütlenmesi sonucu amaç, yetki ve alan çatışmaları ile birlikte eşgüdüm sorunlarının ortaya çıkması (Türker ve ark., 1995), yine Bakanlığın omurgası konumunda olan OGM'de taşra birimlerinin yetkilerinin merkezde toplanması (Bozatl1, 1998), ülkemiz orman kaynakları yönetiminde etkin bir yönetim sergilenmesini güçleştirmiştir.

Öte yandan, AK Partinin tek başına hükümet olduğu ilk üç dönemde (Gül Hükümeti, I. ve II. Erdoğan Hükümetleri) ise, Çevre ve Orman Bakanlığı bünyesinde ormancılık faaliyetlerinin bakanlığa bağl1 dört farklı genel müdürlük tarafindan yürütüldüğü görülmektedir. $\mathrm{Bu}$ dönemde taşra örgütlenmesindeki sorunlar önceki dönemlere nazaran daha büyük boyutlarda yaşanmaya başlanmıştır. Nitekim Bakanlık taşra örgütünü oluşturan İl Çevre ve Orman Müdürlükleri ile ormanc1lık merkez birimleri arasındaki bağlar zayıflamış, ormancilıkla ilgili uzmanlıklar geri planda kalmış (Ekizoğlu ve Akesen, 2006) ve OGM taşra teşkilatı ile eşgüdüm sorunları yaşanmıştır.

Buna karşılık AK Parti tek parti hükümetlerinin son dönemlerinde (III. Erdoğan Hükümeti) Orman ve $\mathrm{Su}$ İşleri Bakanlığı'nın kurulmasıyla birlikte daha önceki genel müdürlüklerden bazılarının daire başkanlığı düzeyine indirilmesi ve bazı yeni genel müdürlüklerin kurulması söz konusudur. Bu değişiklikler de mevcut örgüt yapısında yaşanan sorunlara yeni sorunlar eklenmesine neden olmuştur.

Genel olarak değerlendirildiğinde, bakanlık düzeyinde ormancılık alanında etkili hizmet sunmak amaciyla (Usluoğlu, 1993) hem AP hem de ANAP tek başına hükümetleri tarafindan müstakil bir Orman Bakanlığ kuruluşunun tercih edildiği ve ardından gelen koalisyon vd. hükümetlerce de bu yapının genel olarak sürdürüldüğü anlaşılmaktadır. Buna karşılık AK Parti tek başına hükümet dönemlerinde ise müstakil bir Orman Bakanlığı tercih edilmese de ormancılığın etkinliğinin nispeten fazla olduğu sırasıyla Çevre ve Orman Bakanlığ ile Orman ve Su İşleri Bakanlığı adında bakanlık yapılanmaları söz konusu olmuştur. 
AK Parti tek başına hükümetlerine gelinceye kadar ormancılığın müstakil bir bakanlık olmadığ1 dönemlerde tarımla birlikte tek çatı altında yapılandırıldığı görülmektedir.

Ülke düzeyinde orman kaynakları yönetimi açısından, kabinede sadece ormancılık faaliyetlerinden sorumlu bir bakanın yer alması önemlidir. Bununla birlikte, söz konusu süreçte örgüt yapılanmasında meydana gelen değişiklikler etkinlik düzeyinde daha fazla etkili olmuştur. Nitekim gerek tek parti ve gerekse koalisyon vd. hükümet dönemlerinde ormancilık örgütünde bakanlık düzeyinde yapılan değişiklikler, Çağlar (2012)'ın da belirttiği üzere, mevcut devlet ormancıllğı düzeninin öncelikli alanlarının ve yerleşik çalışma biçimlerinin değişmesine, kurumsal belleğin, olumlu sayllabilecek kimi gelenek ve göreneklerin yitirilmesine de yol açmıştır. $\mathrm{Bu}$ bağlamda, yetki ve sorumlulukları hukuksal düzenlemelerle tanımlanmış olmasına rağmen; AGM, ORKÖY ve MP gibi genel müdürlükler olduğu halde OGM ağaçlandırma, orman köylülerinin kalkındırılması, doğa parkları ve kent ormanları çalışmaları da yapabilmiştir. Dolayısıyla sorunların çözülmesi amacıyla yapılan değişiklikler sonucu, yeni sorunların ortaya çıkması da kaçınılmaz olmuştur.

\section{Ăgaçlandırma ve Orman Tesisi Faaliyetlerine İlişkin Gelişmeler}

Ülkemizde 1960-2012 dönemi

ağaçlandırma ve orman tesisi* faaliyetlerinin gelişimi (URL-4) Şekil 1'de görülmektedir.

İlgili dönem için yapılan Mann-Whitney $\mathrm{U}$ testi sonuçlarına göre, tek başına iktidar olmuş parti hükümetleri ve koalisyon vd. hükümetler döneminde yapılan ağaçlandırma çalışmaları (ha/yıl) arasında anlamlı bir fark bulunmuştur ( $U=197,00 ; p=0,008 ; p<0,05)$. Benzer şekilde tek başına iktidar olmuş parti hükümetleri ile koalisyon vd. hükümetler tarafından yapılan orman tesisi çalışmaları (ha/y1l) arasinda da anlaml bir fark bulunmuştur $(U=129,00 ; p=0,001 ; p<0,05)$.

\footnotetext{
Ağaçlandırma; orman içi ve orman dışı ağaçlandırmaları; orman tesis çalıșması ise ağaçlandırma, rehabilitasyon, erozyon kontörlü, mera ıslahı, özel ağaçlandırma, suni tensil ve enerji ormanı tesisi faaliyetlerini kapsamaktadır.
}

Ağaçlandırma faaliyetleri açısından tek başına iktidar olan partiler ile diğerleri arasında bu tür bir farklılığın ortaya çıkmasında ANAP dönemindeki 93930 ha/yıl düzeyindeki ağaçlandırmanın, 19602012 dönemi genel ortalamasının (39 427 ha/yıl) çok üzerinde olmasından kaynaklandığı ifade edilebilir. 1983-1991 yıllarını kapsayan ANAP döneminde ağaçlandırma faaliyetleri önce artış (1988 yılına kadar) sonra azalış (1991 yılına kadar) göstermiştir. Tartışmaya açık olmakla birlikte ANAP'in kurucusu ve lideri konumundaki Turgut Özal'ın 31 Ekim 1989 tarihinde Başbakanlığ 1 bırakıp, Cumhurbaşkanı olmasının dahi parti politikalarındaki değişim çerçevesinde bu değişimde etkili olduğu ifade edilebilir. Yine de ağaçlandırma faaliyetlerine, ANAP döneminde parti politikalarının da etkisiyle diğer dönemlerden çok daha fazla önem verildiği anlaşılmaktadır. Nitekim, ANAP'ın seçim beyannameleri ve hükümet programlarının büyük çoğunluğunda ağaçlandırmaya ilişkin somut hedeflerin yanı sıra, bu hedeflere ulaşmada ihtiyaç duyulacak işgücünün asker ve gençlerden sağlanacağına ilişkin vaatlerin yer alması (Coşkun ve ark., 2015) ve Türkiye'de ilk defa, 1986 yılında ANAP Hükümeti döneminde özel ağaçlandırma faaliyetlerine başlanması bu önemin bir göstergesi olarak ifade edilebilir. 


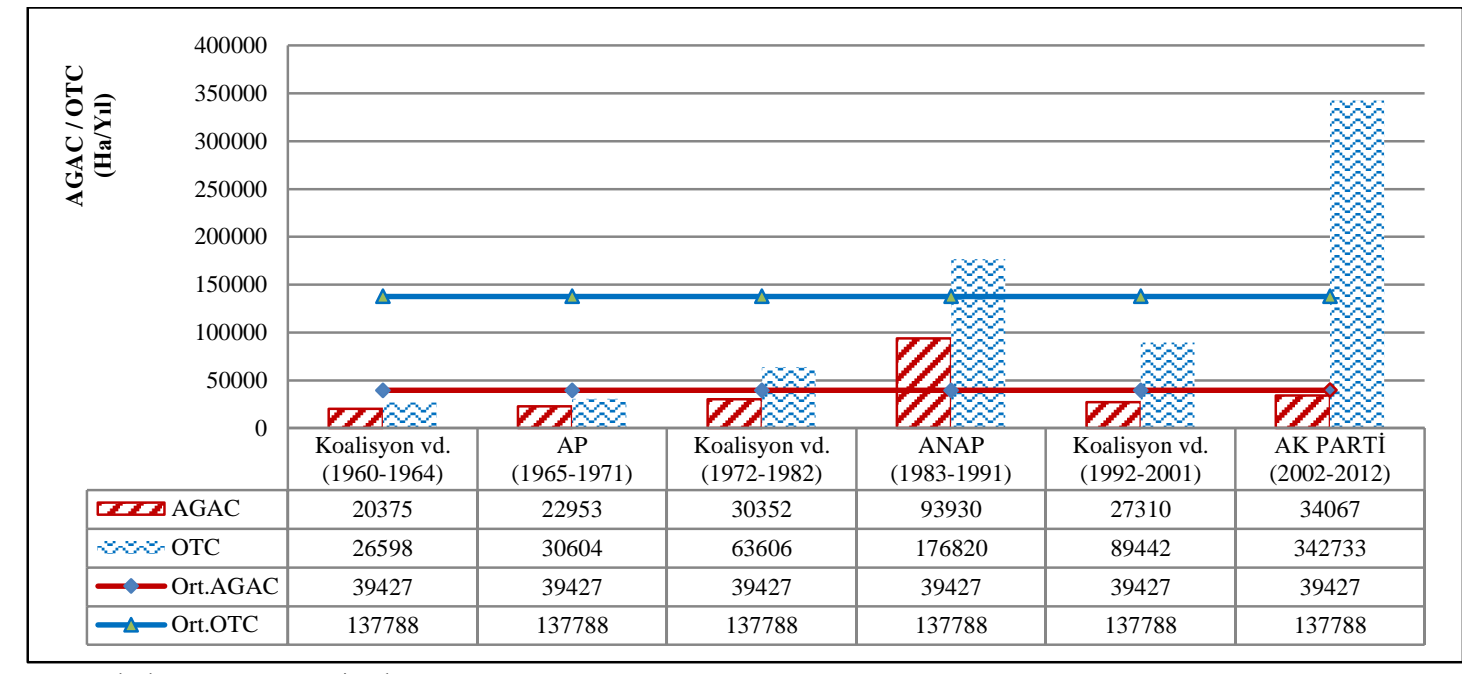

AGAC: Ağaçlandırma OTC: Orman Tesis Calışmas

Kaynak: Ormancılık İstatistikleri 2013

Şekil 1. Ağaçlandırma faaliyetlerinin hükümetler itibariyle gelişimi (1960-2012)

Orman tesisi faaliyetleri açısından tek bașına iktidar olan partiler ile diğerleri arasındaki farklılığın oluşumunda ise, başta AK Parti (2002-2012) ve ANAP (1983-1991) dönemlerinde; ağaçlandırma, rehabilitasyon, erozyon kontrolü, mera 1slahı, suni tensil, enerji ormanı tesisi ile özel ağaçlandırma çalışmalarına verilen önemin etkisi olmuştur. Nitekim orman tesis çalışmaları; ANAP döneminde $176820 \mathrm{ha} / \mathrm{yll}$ ve AK Parti döneminde ise $342733 \mathrm{ha} / \mathrm{y} 1 \mathrm{l}$ ile genel ortalamanın (137 788 ha/yıl) oldukça üzerinde gerçekleşmiştir. Özellikle AK Parti döneminde diğer hükümet dönemlerine nazaran nispeten büyük gerçekleșmelerin sağlanmasında esas olarak AK Partinin seçim planları, hükümet programları ve acil eylem planlarında ağaçlandırma faaliyetlerinin artırılmasına ilişkin somut hedef ve vaatlere ağırlıklı olarak yer vermiş olması (Coşkun ve ark., 2015) ve akabinde de bu hedef ve vaatlerin uygulamaya aktarılmasına dönük irade sergilenmesinin etkili oladuğu ifade edilebilir. Bu bağlamda $\mathrm{AK}$ parti döneminde 2008-2012 yılları için hazırlanan Ağaçlandırma ve Erozyon Kontrolü Eylem Planı'na göre (Anonim, 2007), 5 yıllık dönem için $2 \quad 300 \quad 000$ ha alanda ağaçlandırma, rehabilitasyon, erozyon kontrolü ve mera ıslahı çalışmasının hedeflenmiş olması ve bu hedef doğrultusunda yapılan çalışmalar örnek olarak verilebilir.

AK Parti döneminde orman tesis çalışmalarına ilişkin rakamların büyük oranda artmasında etkili olan faktörlerden en önemlisi OGM tarafindan yapılan rehabilitasyon çalışmalarıdır. Özellikle orman alanı haricinde ağaçlandırılacak alan bulmakta yaşanan zorluklar, bu dönemde bozuk orman alanlarının rehabilitasyonuna ağırlık verilmesine neden olmuştur. Yine bu dönemde bozuk vasıflı mera alanlarında da vasıf değişikliği yapılarak ağaçlandırma ve erozyon kontrol çalışmaları yapılmış ve ağaçlandırma alanlarını artırmak için değişik kurum ve kuruluşlarla (Aile ve Sosyal Politikalar Bakanlığı, Ziraat Odaları Birliği, Diyanet İşleri Başkanlığı vb.) protokoller düzenlenmiştir (URL, 5).

Öte yandan, bahse konu eylem planıyla ilgili ciddi eleştiriler de söz konusudur. Örneğin Çebi (2010) planda ortaya konan hedeflerin \%70'inin rehabilitasyon, \%30'unun ise ağaçlandırma faaliyetinden oluşmasına rağmen, plan kapsamındaki tüm çalışmaların kamuoyuna yeni orman kurmaya dönük faaliyetler yani ağaçlandırma faaliyetleri gibi yansıtılmaya çalışıldığını ifade etmektedir. Benzer şekilde ormancilıkla ilgili bir sivil toplum kuruluşu olan Ormancılar Derneği de ilgili eylem planı kapsamında yapılan ağaçlandırma çalışmaları konusunda ülke kamuoyunun ve hatta uluslararası kuruluşların dahi yanıltıldığını iddia etmektedir (Anonim, 2008). Rehabilitasyon ile ağaçlandırma kapsamları açısından ele alındığında, kamuoyunda oluşan/oluşturulan izlenimler noktasında yapılan eleştirilerin haklı olduğu ifade 
edilebilir. Ancak söz konusu eleștirilerden bağımsız olarak, rehabilitasyon çalışmaları da dahil olmak üzere eylem planı döneminde yürütülen çalışmaların tümünün orman kaynaklarının yönetimi ve orman varlı̆̆ının geleceği açısından olumlu çalışmalar olarak değerlendirilmesi mümkündür.

\section{Odun Üretimine İlișkin Gelișmeler}

Ülkemizde 1963-2012 döneminde OGM odun üretiminin (endüstriyel ve yakacak) gelişimi, Şekil 2'de görülmektedir.

İlgili dönem için yapılan Mann-Whitney $\mathrm{U}$ testi sonuçlarına göre, tek başına iktidar olmuş parti hükümetleri ile koalisyon vd. hükümetler dönemindeki endüstriyel odun üretimleri arasında anlamlı bir fark bulunamamış $(U=215,00 ; p=0,063 ; p<0,05)$, buna karşıllk yakacak odun üretimleri arasında anlamlı bir fark bulunmuştur $(\mathrm{U}=0,00 ; \mathrm{p}=0,000 ; \mathrm{p}<0,05)$.

Tek başına iktidar olan parti hükümetleri ile koalisyon vd. hükümet dönemleri arasında anlamlı fark olmayan endüstriyel odun üretiminin, 1963-2012 döneminde genel olarak bir artış eğilimi sergilediği, ANAP (7 $\left.166000 \mathrm{~m}^{3} / \mathrm{yll}\right)$ ve AK Parti (9 103000 $\left.\mathrm{m}^{3} / \mathrm{y} 1 \mathrm{l}\right)$ dönemleri ile her iki dönem arasındaki koalisyon vd. hükümetler döneminde ( $\left.\begin{array}{lllll}7 & 139 & 000 & \mathrm{~m}^{3} / \mathrm{y} 1 \mathrm{l}\end{array}\right)$ genel ortalamanın (6 $980 \quad 000 \quad \mathrm{~m}^{3} / \mathrm{yll}$ ) üzerinde olduğu görülmektedir.

OGM tarafindan üretilen endüstriyel odundaki genel artış eğilimi, AP döneminde gündeme gelen toplu üretim çalışmaları ve tıraşlama kesimleriyle başlamıştır. Sonrasındaki dönemlerde (1972-2001) ortalama $6500000-7000000 \mathrm{~m}^{3} / \mathrm{y} 1 \mathrm{l}$ seviyelerinde seyreden üretim miktarı, $\mathrm{AK}$ Parti döneminde ise yaklaşı \%30 civarındaki artışla $9000 \quad 000 \quad \mathrm{~m}^{3} / \mathrm{y} 1 \mathrm{l}$ seviyelerine ulaşmıştır (Şekil 2).

Özellikle AK Parti döneminde endüstriyel odun üretimindeki artıșta ülke ekonomisinde yaşanan olumlu gelişmelere paralel olarak gerek inşaat sektöründeki büyüme potansiyeli gerekse orman ürünleri sanayindeki kapasite ve talep artışının etkisi olduğu ifade edilebilir (Anonim, 2013b). Bununla birlikte başta lif yonga odun üretimi ve ardından da tomruk üretiminden kaynaklanan endüstriyel odun üretimindeki artışın, sadece talep odaklı şekillendiğini söylemek de doğru olmayacaktır. Nitekim, söz konusu artışları ormanların potansiyel üretim gücünü de dikkate alan üretim planları ve bu kapsamda söz konusu dönemde gerçekleştirilen artan genç meşcere bakımlarının da bir sonucu olarak değerlendirmek mümkündür (Anonim, 2013c).

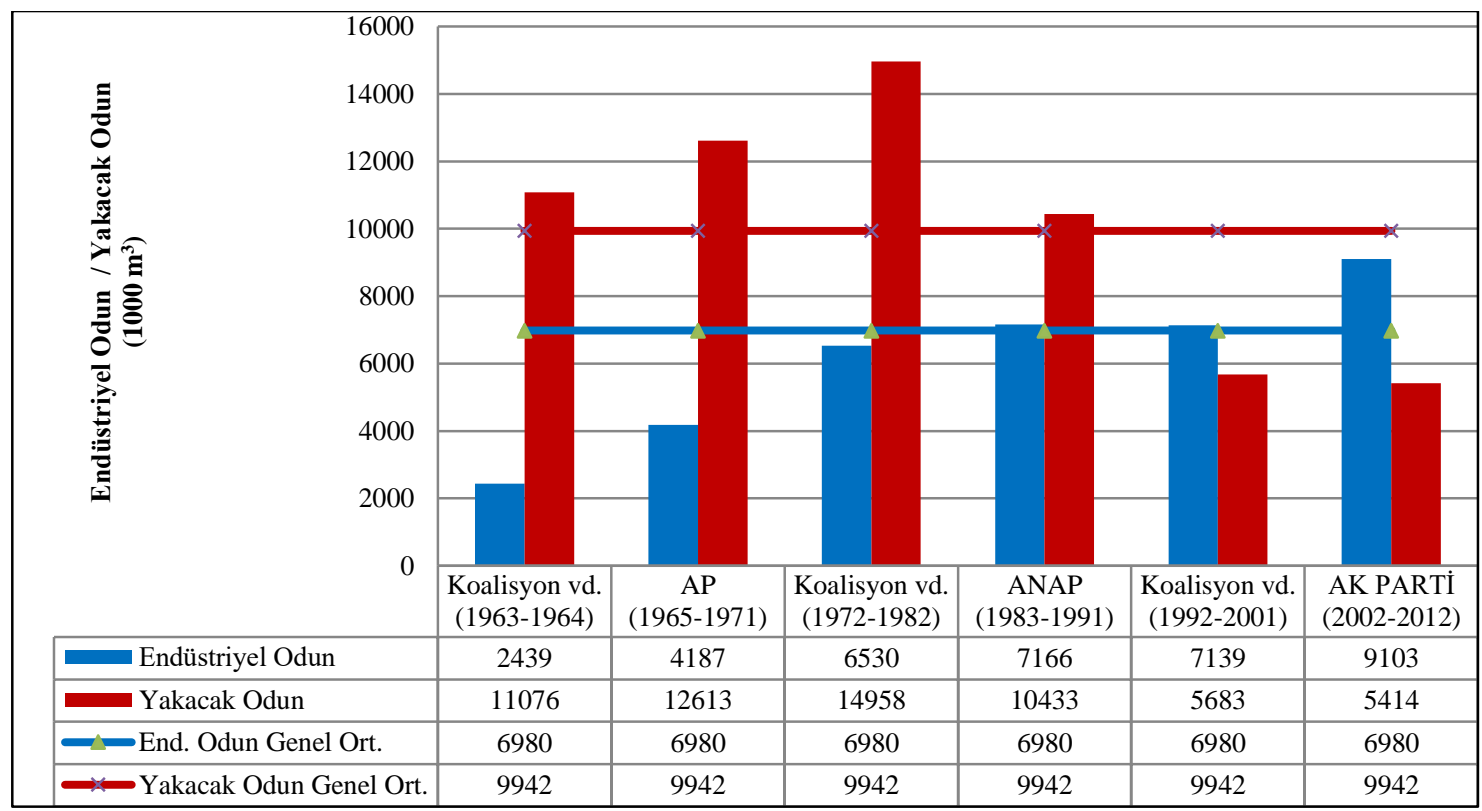

Şekil 2. Odun üretiminin iktidarlar itibariyle gelişimi (1963-2012) 
Üretim miktarlarındaki artış veya azalıșta hükümetlerin etkisi olmakla birlikte, tek başına hükümete bağlamak da doğru bir değerlendirme olmaz. Çünkü ormanlarda ne kadar üretim yapılacağını bilimsel usullere göre yapılan Amenajman Planları ortaya koymaktadır. Hükümetler ancak yol olmadığından işletmeye kapalı ormanlara yol yaptırarak, ormanlar üzerindeki sosyal baskıyı aldığı tedbirlerle ortadan kaldırarak bir miktar üretimi artırabilir. Kald 1 ki endüstriyel odun dışında ürün çeşitleri itibariyle farklı eğilimler söz konusu olabilmekte ve bu eğilimlerin de sanayideki talep gelişiminin yanında artan genç meşcere bakımları paralelinde ve ormanların potansiyelinin limiti dâhilinde şekillendiği görülmektedir (Anonim, 2012a). Dolayısıyla tek parti iktidar dönemleri ile koalisyon vd. hükümet dönemleri arasında odun üretimi açısından anlamlı bir fark ortaya çıkmamasının, üretimi etkileyen ya da kısıtlayan bu tür faktörlerle daha fazla ilişkili olmasından kaynaklandığı düşünülmektedir.

Öte yandan, yakacak odun üretiminin hem tek parti ve koalisyon vd. hükümet dönemleri itibariyle hem de genel itibariyle 1980'lere kadar artıp sonrasında belirgin şekilde azalmasında pek çok faktörün etkisi söz konusudur (Anonim, 2012a). Bu bağlamda hem ANAP hem de AK Parti tek başına hükümetleri dönemlerinde özellikle alternatif enerji kaynaklarının yaygınlaşması, yakmada nispeten daha verimli teknolojilerin kullanılması, endüstride ince odunların da değerlendirilme imkânının artması ve levha sanayiden gelen güçlü talebin baskısı yanı sıra; zamanla köyden şehre göç sonucu, köylülerin zati yakacak odun talebinin giderek azalması gibi faktörleri saymak mümkündür.

Orman Kadastro Çalışmalarına İlişkin Gelişmeler

Araştırma kapsamında AP ve ANAP tek başına hükümet dönemleri için yıllar itibariyle kadastrosu yapilan orman alanlarına ilișkin güvenilir ve sürekli veriler elde edilememiştir. Kadastrosu yapılan orman alanına ilişkin sadece 2003 yılı ve sonrasina ait yıllık veriler elde edilebildiğinden, söz konusu veriler araştırma amacı doğrultusunda AK Parti (2003-2011) ile diğer parti hükümetleri dönemi (1957-2002) şeklinde iki dönem halinde ele alınabilmiştir.

Tablo 3'ten görüleceği üzere, 1937-2002 tarihleri arasında Türkiye ormanlarının ancak yarısına yakınında (10 228311 ha) kadastro bitirilirken, 2003-2011 döneminde ise 8343 664 ha ormanın kadastrosu yapılmıștır. Buna göre AK Parti döneminde yapılan orman kadastrosu (927 074 ha/yıl), diğer partilerin hükümetleri döneminde yapılanın (159007 ha/yıl) yaklaşık altı katına karşılık gelmektedir (Şekil 3).

Tablo 3. Yıllar itibariyle kadastrosu yapılan orman alanı (ha)

\begin{tabular}{ccc}
\hline Yıllar & Kadastrosu Yapılan Orman Alanı & Kümülatif Toplam \\
\hline $1937-1956$ & 2914000 & 2914000 \\
$1957-1973$ & 1425000 & 4339000 \\
$1974-1983$ & 1644000 & 5983000 \\
$1984-1985$ & 233311 & 6216311 \\
$1986-2002$ & 4012000 & 10228311 \\
2003 & 644840 & 10873151 \\
2004 & 328746 & 11201897 \\
2005 & 594719 & 11796616 \\
2006 & 1336799 & 13133415 \\
2007 & 1690908 & 14824323 \\
2008 & 1367118 & 16191441 \\
2009 & 966818 & 17158259 \\
2010 & 563716 & 17721975 \\
2011 & 850000 & $\mathbf{1 8 5 7 1 9 7 5}$ \\
\hline Toplam & $\mathbf{1 8 5 7 1 9 7 5}$ &
\end{tabular}


Verilerin yeterli olmamas1, ANAP döneminde gerçekleştirilen kadastro çalışmalarının değerlendirilmesini güçleştirmektedir. Buna rağmen, ANAP'ın tek başına iktidar olduğu dönemde gerek seçim beyannameleri ve gerekse hükümet programlarında kadastro konusunun öncelikli çözülecek sorunlar arasında sayılması
(Coșkun ve Ark., 2015), 3402 sayılı Kadastro Kanununun 1987 yılında çıkarılmış olması ve 6831 say1l Orman Kanunu'nda kadastro çalışmalarını hızlandırmayı amaçlayan düzenlemelerin yapılması ANAP'in kadastro çalışmalarına verdiği önemin bir göstergesi olarak düşünülebilir.

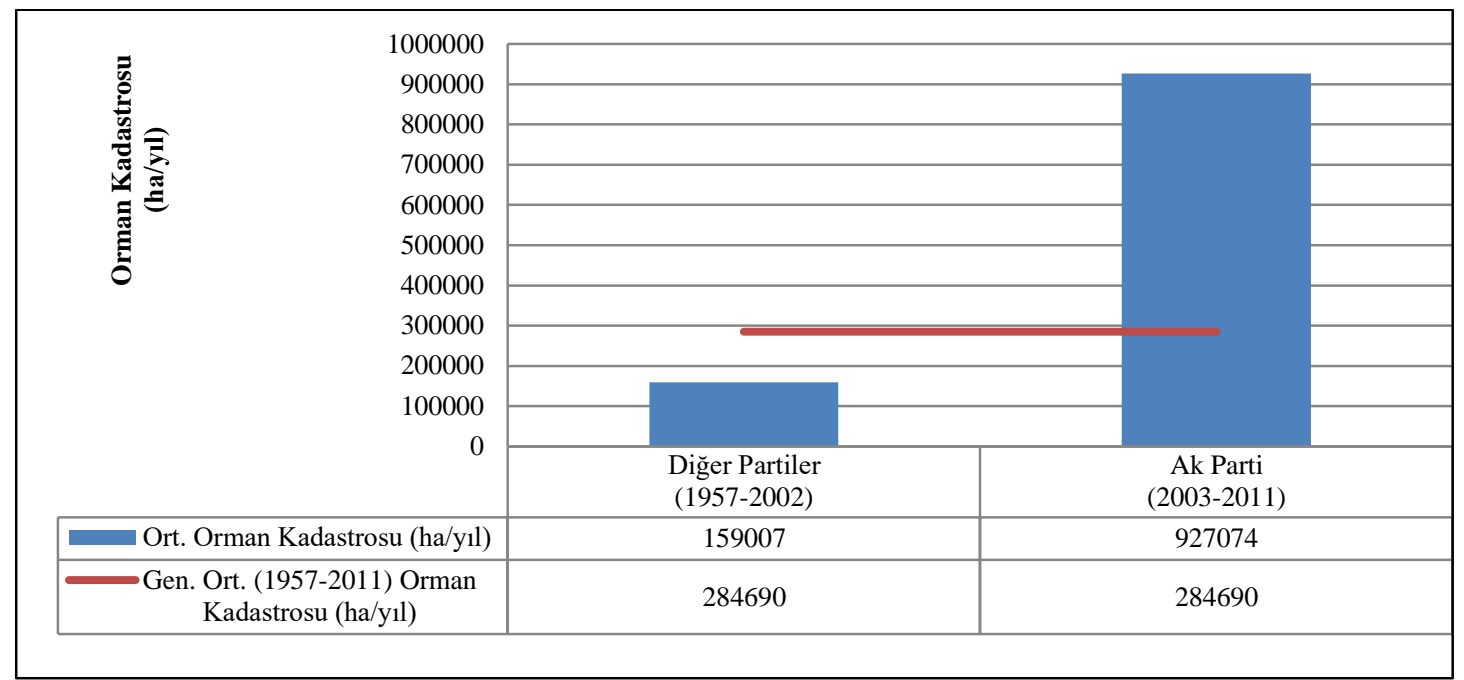

Şekil 3. Kadastro faaliyetlerinin gelişimi (1957-2011)

AK Parti döneminde kadastro çalışmalarının geçmiş dönemlere göre fazla olmasının en büyük sebebi, 22.2.2005 tarihinde çkarılan Kadastro Kanununda Değişiklik Yapılması Hakkındaki 5304 sayılı Kanunla getirilen yenilikler olmuştur. 5304 sayılı Kanun çıkarılıncaya kadar Türkiye'de iki ayrı kadastro uygulamas1; yani kadastro konusunda iki başl1lık söz konusu olmuştur. Bir taraftan ormanlık alanlarda OGM'ce görevlendirilen orman kadastro komisyonları, diğer taraftan da orman alanları haricinde Tapu Kadastro Genel Müdürlüğünce görevlendirilen kadastro ekipleri kadastro yapmış ve bu durum aynı zamanda uygulamada çeşitli sorunları da beraberinde getirmiştir.

2005 y1lında çıkarılan 5304 sayılı Kanun ile 3402 sayılı Kadastro Kanununun 4. maddesinde yapılan değişiklik ile hem kadastro tek elden yapılmaya başlanılmıș, hem de çalışmalara muhtar ve bilirkişilerin katılmaması durumunda komisyonlara re'sen kadastro yapma yetkisi verilmiştir. Zira, özellikle kadastronun geçmesi durumunda kullandıkları arazilerin ormana kalacağını ve ellerinden çıkacağını düşünen köy muhtarlarının çalışmalara katılmamaları ve bu şekilde kadastro çalışmalarını engellemeleriyle karşılaşılmıştır. Değişiklik sayesinde getirilen "çalışmalar re'sen devam ettirilir" hükmü ile muhtarların kadastro çalışmalarını engellemesinin önüne geçilmiştir. Böylece Tablo 5'ten görüleceği üzere, 2005 y1lından sonra y1llık ortalama kadastrosu yapılan alan miktarı önceki yıllara göre 2-3 kat artmıştır.

Yine AK Parti döneminde ormanların kadastrosu konusunda yaşanan önemli sorunlardan biri olan eski teknikle (grafik yöntemle) yapılan kadastro çalışmalarının tescili sorununu çözmek ve $2 \mathrm{~B}$ ve tescil (tapu) işlerini bitirmek üzere 06.01.2012 tarihinde OGM ile Tapu ve Kadastro Genel Müdürlüğü arasında "Orman Kadastro Çalışmaları ve Teknik Hataların Düzeltilmesi İşlemlerinde" karşıllklı işbirliği esaslarını düzenleyen bir protokol imzalanmıștır. Ayrıca, 19.4.2012 tarihinde çıkarılan 6292 sayıl1 kanunla 6831 sayıl Orman Kanunu'nun 10. maddesine yapilan ekleme ile orman kadastro çalışmalarına Tapu ve Kadastro Genel Müdürlüğü taşra teşkilatınca kontrol mühendisi görevlendirilmesi zorunlu 
kı1ınmıștır. $\mathrm{Bu}$ durum da yapılan orman kadastro çalışmalarının tescilindeki sorunu ortadan kaldırmıştır.

Öte yandan, Türk ormancılığının son dönemlerinin en tartışmalı konularından biri olan (Erdönmez, 2013) orman sınırları dışına çıkarılmasına ilişkin uygulamalar üzerinde ayrıca durulması gerekmektedir. Günümüzde kamuoyunda kisaca 2B olarak bilinen bu uygulamalar III. Demirel Hükümeti tarafindan 1970 yılında çıkarılan 1255 sayılı yasa ile 1961 Anayasasının 131. maddesinin değiştirilmesiyle başlamıştır (Coşkun ve ark., 2015). Bu süreç sonucunda, ANAP tek başına iktidarının bir kısmını da içine alan 1986-2000 döneminde, yaklaşı 250 bin ha (Çağlar, 2012), 2012 yılı sonu itibariyle de 410000 ha orman alanı orman sınırları dışına çıkarılmıştır (Tablo 4).

Tablo 4. Türkiye'de orman kadastrosuna ilişkin gelişmeler

\begin{tabular}{|c|c|c|c|c|}
\hline Yillar & Uygulanan Kanun & 2. Madde Uygulaması & 2/B Madde Uygulaması & \\
\hline 1973-1982 & 6831 ve 1744 & 102560 & & \\
\hline 1983-1986 & 6831 ve 2896 & & 27030 & \\
\hline 1987-2012 & 6831,3402 ve 3302 & & 280410 & \\
\hline Toplam & & 102560 & 307440 & 410.000 \\
\hline
\end{tabular}

2B uygulamaların gerekçesine bakıldığında, bu alanların zaten orman niteliğini kaybettiği, üzerinde yapılaşmanın olduğu anlaşılmaktadır. Ancak böyle bir düzenlemenin kadastrosu yapılmamış ormanlar üzerindeki baskıyı artıracağı, ormanların işgal edilmesini teşvik edeceği, ormanların sürdürülebilirliğini tehdit edeceğine yönelik kaygıları da göz ard1 etmemek gerekir (Ayaz, 1998). Nitekim, 2B ile orman niteliğini kaybeden alanların orman sınırları dışına çıkarılması uygulamaları, hukuksal dayanağı olan ancak gerekçeleri bilimsel olmayan ve ormanlara zarar veren kişilerin ödüllendirildiği bir süreç olarak değerlendirilmektedir (Çağlar, 2000). Keza bu uygulamaların Türkiye ormanlarının 20 yılını planlayan Türkiye Ulusal Ormancılık Programının ilke, amaç, politika ve stratejileriyle de büyük ölçüde uyumsuz olduğu ifade edilmektedir (Erdönmez, 2013).

$\mathrm{Bu}$ noktada, ülkemiz ormanlarının sinırlandırılıp güvence altına alınmasını doğrudan veya dolaylı biçimde etkileyen yasal değişikliklerin oldukça sık gerçekleştirilmesi ve bu değişiklikler nedeniyle çalışma yapılan alanlara tekrar tekrar gidilmesi orman kadastrosunu çözülemeyen bir sorun olarak tetikleyen nedenlerden biri olarak görülmesine neden olmaktadır (Türker ve ark., 1995). Etkin ve verimli bir orman kaynakları yönetimi ve işletmeciliği için öncelikle üzerinde işletme faaliyetlerinin yapıldı $\breve{g}_{1}$ orman arazisinin sınırlarının belirlenmiş olması yani kadastro çalışmasının tamamlanmış olması gerekmektedir (Türker ve ark. 1999). Bundan dolayıdır ki 1937 yılında çıarılan 3116 sayılı Orman Kanunu ile ülkemiz ormanlarının tahdidinin beş yılda, kadastrosunun da 10 yılda tamamlanmas öngörülmüştür (Resmi Gazete, 1937). Ancak aradan 75 y1l geçmesine rağmen (2011 y1l sonu itibariyle) Türkiye ormanlarının (yaklaşık 21,7 milyon ha) \%87'sinin orman kadastrosu tamamlanabilmiştir (Anonim, 2012b). Bu orana ulaşılmasında çeşitli olumsuz sonuçlar doğurmasina rağmen özellikle son y1llarda yapılan yasal düzenlemeler ve buna bağlı uygulamaların etkisi büyüktür.

\section{Sonuç ve Öneriler}

Araştırma döneminde; ormancıllk yönetimi, ağaçlandırma ve orman tesisi faaliyetleri, odun üretimi ve orman kadastro çalışmaları bağlamında yaşanan gelişmeler hükümet dönemleri itibariyle aşağıda özetlenmiștir:

AP ve ANAP tek parti iktidarı dönemlerinde müstakil bir Orman Bakanlığ kuruluşu söz konusu iken, AK Parti döneminde önce Çevre ve Orman ve ardından Orman ve $\mathrm{Su}$ İșleri Bakanlığı şeklinde bir yapılanma söz konusudur. Öte yandan koalisyon vd. hükümet dönemlerinde ise ormancılığın tarımla birlikte bakanlık düzeyinde örgütlendiği görülmektedir. Tüm bu bakanlık yapılanmalarında ormanc1lıkla ilgili bazı genel müdürlükler zaman zaman 
kurulmasına ve kapatılmasına rağmen değişmeyen yegâne birim olan OGM müstakil bir orman bakanlığının olmadığı dönemlerde adeta ormancilığın güvencesi olmuştur. Bakanlık ve bağlı merkez ve taşra birimlerinde yapılan bu tür değişiklikler sürekli yeni sorunların ortaya çıkmasına neden olmuş ve etkin bir yönetim sergilenmesini engellemiştir.

Öte yandan, tek parti hükümet dönemleri ile koalisyon vd. hükümet dönemleri, gerek ağaçlandırma gerekse ağaçlandırmayı da içine alan orman tesisi çalışmaları açısından karșılaștırıldığında tek parti hükümet dönemleri lehine anlamlı bir fark söz konusudur. Bir başka ifadeyle araştırma döneminde tek parti iktidarları döneminde diğer dönemlere göre yıllık ortalama ağaçlandırma ve orman tesisi çalışması çok daha fazla gerçekleştirilmiştir. Bu farklılığın ortaya çıkmasında ağaçlandırma açısından ANAP, orman tesisi açısından AK Partinin daha önde olduğu görülmektedir.

Endüstriyel odun üretimi açısından tek parti ile koalisyon vd. hükümet dönemleri arasında anlamlı bir fark bulunamamıștır. Odun üretimi açısından anlamlı bir fark ortaya çıkmaması, üretimi etkileyen (sanayi talebi, ekonomik gelişmeler vb) ya da kisitlayan (amenajman planları, pazar talebinin düşmesi vb.) diğer faktörlerin daha baskın olmasından kaynaklanmış olduğu düşünülmektedir. Buna karşıllık yakacak odun açısından tek parti ve koalisyon vd. hükümet dönemlerinde görülen farkta, özellikle ANAP ve AK Parti dönemlerinde alternatif enerji kaynaklarının yaygınlaşması, kentlere göçle yakacak odun talebinin azalması vb. değișkenler etkili olmuștur.

Kadastro çalışmaları açısından bakıldığında, AK Parti döneminde yapılan y1llık ortalama orman kadastrosu, diğer partilerin hükümetleri döneminde yapılanın yaklaşık altı katına karşılık gelmektedir. Dolayısıyla özellikle mevzuat açısından yapılan değişiklikler özellikle AK Parti döneminde orman kadastrosu konusunda ciddi mesafeler alınmasına neden olmuştur. Bununla birlikte ANAP döneminde de orman kadastro çalışmalarını hızlandırmaya dönük çalışmalar söz konusudur.

$\mathrm{Bu}$ araştırmada üzerinde yoğunlaşılan AP, ANAP ve AK Partinin tek bașina iktidar oldukları dönemlerdeki ormancılıkla ilgili başlıca uygulamalar dikkatle incelendiğinde; bütün gelişmelerin halkın ya da ormancilıkla ilgili kesimlerin (tarım, sanayi, maden, turizm vb.) ihtiyaçlarından ve taleplerinden ortaya çıktığ 1 görülmektedir. $\mathrm{Bu}$ nedenle halkın oylarıyla hükümet olan seçilmişlerin kendilerini seçenlerin isteklerine, ilgili sektörlerin ve ülkenin ihtiyaçlarına göre düzenlemeler yapmaları ve icraatlarda bulunmaları son derece doğaldır. Nitekim bu üç partinin tek başına iktidarda oldukları dönemlerde, seçim beyannameleri ve hükümet programları arasında büyük ölçüde bir tutarlılığın söz konusu olduğu ve ilgili hükümetlerin icraatlarıyla da bu tutarlılığın daha da pekiştirildiği ifade edilmektedir (Coşkun ve ark., 2015). Ancak bu noktada zaman zaman sıkıntılar yaşandığı, siyasi kaygıların zaman zaman ön plana geçtiği de olmuştur. Burada esas olarak üzerinde durulmas1 gereken husus, siyasetçilerin bu süreçte seçmeni ve diğer ilgili kesimleri memnun ederken, diğer taraftan ormanların kendine özgü hassas bir ekosistem olduğu gerçeğini göz ardı etmemeleri ve orman kaynaklarının sürdürülebilirliğini sekteye uğratabilecek girişimlerden uzak durmalarının sağlanmasıdır.

Bu noktada, orman kaynakları yönetimini olumsuz yönde etkileyebilecek sonuçların ortaya çıkmaması için, ormanların sağladığı ekonomik, sosyal ve çevresel faydalar ve önemi konusunda, ormancılık teşkilatı ve ormancılık ile ilgili sivil toplum örgütleri öncülüğünde toplumun bütün kesimlerinde ve özellikle de siyasi karar vericilerde farkındalık oluşturulması gerekmektedir.

\section{Kaynaklar}

Anonim. 1989. Kuruluşunun 150. Yılında Ormanc1lı̆̆ımız. Orman Genel Müdürlüğü Yayını No:673/30, Ankara.

Anonim. 2001. Sekizinci Beş Yıllık Kalkınma Planı Ormanc1lık Özel İhtisas Komisyonu Raporu. DPT Yayın No:2531, Ankara.

Anonim. 2004. Türkiye Ulusal Ormancilık Programı. Çevre ve Orman Bakanlı̆̆ı, Ankara.

Anonim. 2007. Ağaçlandırma ve Erozyon Kontrolü Seferberliği Eylem Planı (2008-2012), Çevre ve Orman Bakanlığı, Ankara.

Anonim. 2008. Çevre günü kutlanmalı mı? Orman ve Av Dergisi 3,2-2. 
Anonim. 2012a. Ormanlardan faydalanma şûra çalışma belgesi (Çalışma Grubu 10). Ormancilık ve Su Şûrası 2013, 21-23 Mart 2013, Ankara, 43 s., (sura.ormansu.gov.tr/sura/Files/ÇG.10OrmanlardanFaydalanma.doc, Ziyaret tarihi:15.01.2015).

Anonim. 2012b. Orman Genel Müdürlüğü Stratejik Plan 2013-2017. http://www.sp.gov.tr/tr/stratejik-

plan/s/889/Orman+Genel+Mudurlugu+20132017 (Ziyaret tarihi:15.06.2015).

Anonim. 2013a. Orman ve Su İşleri Bakanlığı Stratejik Plan 2013-2017. http://sgb.ormansu.gov.tr/strateji/files/Stratejik_Pl an/mobile/index.html (Ziyaret tarihi:03.04.2015).

Anonim. 2013b. Orman İşletmeciliğinde Üretim Pazarlama Faaliyetleri. Orman Genel Müdürlüğü İşletme ve Pazarlama Daire Başkanlığı Eğitim Notları, www.ogm.gov.tr/.../Egitim/IŞLETME\%20PAZA RLAMA\%20EĞİTiM.doc (Ziyaret tarihi:01.04.2015)

Anonim. 2013c. UNNF-10 Oturumunda Ele Alınacak Konularla İlgili Taslak Bilgi Notu, TC Orman ve Su İşleri Bakanlığı, $135 \mathrm{~s}$.

Atmiş E. 2008. 2007 Genel seçim bildirgeleri çerçevesinde siyasi partiler ve ormancılık ilişkileri. Bartın Orman Fakültesi Dergisi 10(14): 33-42.

Atmiş E., Gençay G. 2014. Cumhuriyetin ilk yıllarındaki ormancılık politikalarının yerel yansımaları (Bartın Gazetesi örneği) IÜ Orman Fakültesi Dergisi 64(2):1-13.

Atmiş E., Günşen H.B. 2009. Türkiye'de hükümetlerin ormancılık politika ve uygulamaları üzerine eleştirel bir değerlendirme-AKP örneği. Orman ve Av Dergisi 2009/2:33-42.

Atmiş E., Günșen H.B. 2011. 2011 Genel seçimlerinde siyasi partiler ve ormancilık ilişkileri. Kastamonu Orman Fakültesi Dergisi 11(2):191-204.

Ayaz H. 1998. Orman Sinırları Dışına Çıkarma Uygulamasının Yasal Boyutu ve SosyoEkonomik Nedenleri Üzerine Bir Araştırma. Yüksek Lisans Tezi, KTÜ Fen Bilimleri Enstitüsü, Trabzon.

Benli M. 2014. Türkiye Cumhuriyeti'nde Ormancılık Politikaları (1923-1946). Yüksek Lisans Tezi, Sultan Mehmet Vakıf Üniversitesi.

Birben Ü. 2008. Türkiye'de 1937 yllından sonra ormancılık mevzuatında yaşanan gelişmeler ve toplumsal yaşamla etkileşimler. $\dot{I} \ddot{U}$ Orman Fakültesi Dergisi Seri A 58(1):1-16.

Bozatlı A. 1998. Cumhuriyet Döneminde orman teşkilatının örgütsel ve işlevsel gelişimi. Cumhuriyetimizin 75. Yılında Ormancılığımız
Sempozyumu, İstanbul, 21-23 Ekim 1998, s. 1220.

Çağlar Y. 2000. Biz Gideriz Ormana. 307 s., Ankara.

Çağlar Y. 2012. Türkiye Ormancılık Tarihi. ODTÜ Yayıncılık, Ankara.

Çebi F. 2010. Ağaçlandırma Seferberliği (2008-2012), Orman Mühendisliği Dergisi 47(45-6), 30-33.

Coşkun, A.K. 2013. Ülkemiz Tek Parti İktidarlarında Ormancılıkla İlgili Hükümet Vaat Ve İcraatlarının Orman Kaynakları Yönetimi Ve İşletmeciliği Açısından Değerlendirilmesi, AÇÜ Fen Bilimleri Enstitüsü Yüksek Lisans Tezi (Yayımlanmamıștır), $127 \mathrm{~s}$.

Coşkun A.K., Türker M.F., Öztürk A. 2015. Türkiye'de tek başına iktidar olan partilerin seçim beyannameleri ve hükümet programlarında ormanc1lık, $A C ̧ \ddot{U}$ Orman Fakültesi Dergisi 16(1):72-88.

Daşdemir İ. 2011. Orman Mühendisliğine Giriş Ders Notu. Bartın. (bbs.bartin.edu.tr/dosyalar/DersMateryal/ormanm ühendisliğinegiriş.pdf

(Ziyaret tarihi:20.02.2015)).

Ekizoğlu A., Akesen A. 2006. Tarihi süreç içinde ormancılık örgütünde görülen yapısal dalgalanmalar, Ormancilikta Sosyo-Ekonomik Sorunlar Kongresi, 26-28 Mayıs 2006, IlgazÇankırı, 157-162.

Erdoğan M. 2013. Seçim Sistemleri İle Siyasi Partiler Arasındaki İlişkiler. Yüksek Lisans Tezi, Gazi Üniversitesi.

Erdönmez C., Atmış A., Özden S. 2010. Türkiye'de ormancılık politikası. In: Akesen, A., Ekizoğlu, A. (Eds), Ormancılık Politikası, Türkiye Ormancılar Derneği Eğitim Dizisi Yayın No:6, Ankara, pp 102-146.

Erdönmez C. 2013. 2B Alanlarının Satışının Türkiye Ulusal Ormancılık Programı Açısından İrdelenmesi, Kastamonu Üniversitesi Orman Fakültesi Dergisi 13(2):307-324.

Gözler, K. 2000. Türkiye'de Hükümetlere Nasıl İstikrar ve Etkinlik Kazandırılabilir? (Başkanlık Sistemi ve Rasyonelleştirilmiş Parlamentarizm Üzerine Bir Deneme), Türkiye Günlüğü, Sayı 62, Eylül-Ekim 2000, s.25-47 (http://www.anayasa.gen.tr/index-kitapmakaleler.htm, et: 04.02.2016)

Özdamar K. 2004. Paket Programlar İle İstatistiksel Veri Analizi. Genişletilmiş 5. Baskı, Kaan Kitabevi, Eskişehir.

Özdönmez M., Akesen A., Ekizoğlu A. 1998. Cumhuriyet ormancılığındaki dönüm noktaları, Cumhuriyetimizin 75. Yilında Ormancılı̆̆ımız Sempozyumu, İstanbul, 21-23 Ekim 1998, s. 311 , 
Resmi Gazete. 1937. Orman Kanunu, Kanun No:3116, Kabul Tarihi: 8.2.1937,Yayımlandığ1 Resmi Gazete Tarihi: 13.02.1937, Say1: 3537

Türker M.F., Gümüş C., Ayaz H. 1995. Türkiye'de orman ekonomisi ile ilgili sorunlar ve çözüm önerileri, Türkiye Ormancllık Raporu, KTÜ Orman Fakültesi Yayın No:48, s.80-102.

Türker M.F., Pak M., Öztürk A. 1999. Ormancilık Sektöründe Orman Kadastro Çalı̧̧maları ve Orman Mülkiyet Sorunlarının Ülke Kalkınma Planları ve Ormancilık Yasal Mevzuatı Çerçevesinde Değerlendirilmesi, Doğu Karadeniz Bölgesinde Kadastro ve Mülkiyet Sorunları Sempozyumu, Trabzon, 11-12 Ekim 1999, s:193-204.

Türker, M.F., Yılmaz, C. 2010. Doğu Karadeniz, Türkiye ve Dünya Ormancıllğının Sorunları ve Bu Sorunları Doğuran Köksorunların İrdelenmesi, III. Ulusal Karadeniz Ormancillk Kongresi, Artvin Çoruh Üniversitesi Orman Fakültesi, Bildiriler Kitab1 I. Cilt, 80-92s, 20-22 Mayis 2010, Artvin.

URL

http://www.agm.gov.tr/AGM/Files/taniti

m-organizasyon/tarihce.PNG, AGM'nin Tarihçesi, (Ziyaret tarihi: 31.07.2012).

URL 2. http://www2.ogm.gov.tr/istatistikler, Erişim Tarihi: 31.07 .2012

URL 3.

http://www.agm.gov.tr/AGM/AnaSayfa/istatistikl er.aspx?sflang=tr, $1946-2010$ Yillar İtibariyle Yapılan Orman Tesisi Çalışmaları (Ziyaret tarihi: 31.06.2012).

URL 4.

http://www.ogm.gov.tr/ekutuphane/istatistikler/fo rms/allitems.aspx? RootFolder $=\% 2$ Fekutuphane $\%$ 2FIstatistikler\%2FOrmanc\%C4\%B11\%C4\%B1k $\% 20 \% \mathrm{C} 4 \% \mathrm{~B} 0$ statistikleri\&FolderCTID $=0 \mathrm{x} 01200$ 0301D182F8CB9FC49963274E712A2DC00\&Vi ew $=\{$ C19AB316-F6A1-40F4-BE44-

7526AE967FDC\}, Ormancilik İstatistikleri 2013. (Ziyaret tarihi: 25.06.2015).

URL 5.

http://web.ogm.gov.tr/birimler/merkez/agaclandir ma/Ozelliklialanagaclandirmalari_Dokumanlar /Forms /AllItems.aspx (Ziyaret tarihi:

17.08.2012).

Usluoğlu H.A. 1993. Orman Bakanlığı neden gerekli?, I. Ormancılık Şurası, Ankara, 1-5 Kasım 1993, Tebliğler ve Ön Çalışma Grubu Raporları Cilt 1:165-167.

Yazıcı K. 1990. Ormancılığımızın 150. yilında orman idaresi ve orman işletmeleri, 150 . Yılında Türk Ormanc1lığı Paneli, Ankara, s. 205220. 